\title{
Effect of Oxidation Temperature on Magnetron Sputtered Zirconium Niobium Films
}

\author{
Bukke Gopal Naik ${ }^{1}$, Sangaraju Venkata Jagadeesh Chandra ${ }^{2, *} \mathbb{D}$, Chanamolu Swathi ${ }^{3}$, Suda Uthanna ${ }^{1, *}$ \\ Department of Physics, Sri Venkateswara University, Tirupati - 517 502, India; dr.sangaraju @ gmail.com (B.G.N.); \\ 2 Department of Electronics and Communication Engineering, Vignan's Institute of Information Technology, \\ Visakhapatnam - 530 046, India; svjchandra@gmail.com (S.V.J.C.); \\ 3 Nanotechnology Laboratory, Department of Instrument Technology, Andhra University, Visakhapatnam, Andhra Pradesh, \\ India; chandusvj@yahoo.com (C.S.); \\ * Correspondence: svjchandra@gmail.com(S.V.J.C.), uthanna.suda@gmail.com (S.U.);
}

Scopus Author ID 24076172500

Received: 3.04.2021; Revised: 1.05.2021; Accepted: 6.05.2021; Published: 18.06.2021

\begin{abstract}
Thermal treatment was performed on DC magnetron sputtered zirconium niobium $\left(\mathrm{Zr}_{0.7} \mathrm{Nb}_{0.3}\right)$ films in the oxygen-enriched environment at different temperatures in the range $400-700^{\circ} \mathrm{C}$ to transform from $\mathrm{Zr}_{0.7} \mathrm{Nb}_{0.3}$ to $\mathrm{Zr}_{0.7} \mathrm{Nb}_{0.3} \mathrm{O}_{2}$ films. The films oxidized at $700^{\circ} \mathrm{C}$ were of tetragonal $\mathrm{Zr}_{0.7} \mathrm{Nb}_{0.3} \mathrm{O}_{2}$ with a crystallite size of $22 \mathrm{~nm}$. There was a significant increase in the optical transmittance of the $\mathrm{Zr}_{0.7} \mathrm{Nb}_{0.3} \mathrm{O}_{2}$ films from $75 \%$ to $90 \%$, and eventually, the optical band gap also increased from 4.32 to $4.61 \mathrm{eV}$ by increasing the oxidation temperature from 400 to $700{ }^{\circ} \mathrm{C}$, respectively. The metaloxide-semiconductor stacks of $\mathrm{Al} / \mathrm{Zr}_{0.7} \mathrm{Nb}_{0.3} \mathrm{O}_{2} / \mathrm{p}$-Si showed higher dielectric constant values with improved interface quality at oxide/ $\mathrm{Si}$ stack upon thermal oxidation at $700^{\circ} \mathrm{C}$ with relatively lower leakage currents.
\end{abstract}

Keywords: $\mathrm{Zr}_{0.7} \mathrm{Nb}_{0.3} \mathrm{O}_{2}$ thin films;structure; FTIR; XPS;optical;dielectric constant; leakage currents.

(C) 2021 by the authors. This article is an open-access article distributed under the terms and conditions of the Creative Commons Attribution (CC BY) license (https://creativecommons.org/licenses/by/4.0/).

\section{Introduction}

Zirconium oxide $\left(\mathrm{ZrO}_{2}\right)$ is familiarly known as zirconia. It is prominent material for device applications because of its high mechanical strength, fracture toughness, thermal insulation, high transparency, and resistance to erosion[1]. On the other hand, $\mathrm{ZrO}_{2}$ shows good thermal stability with silicon and has a high dielectric constant is considered a promising candidate for conventional very large-scale integration processing [2]. Its high refractive index, large bandgap, insignificant optical losses, and high transparency in the visible region made it useful for high reflectance mirrors, active optoelectronic devices, and broadband filters [3-5]. In recent years, much attention is focused on the doped zirconium oxide thin films for optoelectronic devices. Hydrogenated zirconium oxide is a potential candidate for application in solid-state ionic energy devices [6]. Aluminum-doped zirconium oxide leads to the tuning of the refractive index for optoelectronic applications [7]. Gold doped zirconium oxide coatings realized strong visible light absorption due to localized surface plasmon resonance for use in plasmonic devices such as lenses, switches, and waveguides [8]. Copper doped $\mathrm{ZrO}_{2}$ nanoparticles grab attraction for photocatalytic applications [9]. Atomic layer deposited $\mathrm{CeO}_{2}$ - $\mathrm{ZrO}_{2}$ films are potential for solid-state oxide fuel cells [10], $\mathrm{HfO}_{2}-\mathrm{ZrO}_{2}$ films in electrostatic supercapacitors [11], $\mathrm{ZrO}_{2}-\mathrm{TiO}_{2}$ films as corrosion resistance [12], and sensing of oxygen, hydrogen, methane, and carbon monoxide gases [13]. Doping of yttrium /calcium in zirconium 
oxide films spread a broad range of refractive index, which is attractive for wide optic applications [10]. There was a significant role of niobium compound films for various societal applications [14-16]. Zirconium niobium alloy oxide finds multiple applications for microelectronics and optical devices $[17,18]$. The addition of niobium $(\mathrm{Nb})$ increases the TiZr alloy's stability and biologic corrosion resistance [19]. Santos et al. [20] deposited Nb-doped $\mathrm{ZrO}_{2}(\mathrm{Nb}=19-50 \mathrm{wt} . \%)$ films by spark anodization method and noticed that the films were a mixed phase of hexagonal zirconium, tetragonal along with monoclinic $\mathrm{ZrO}_{2}$ and tetragonal $\mathrm{Nb}_{2} \mathrm{O}_{5}$, and the grain size increased with the increase of niobium content.

In this investigation, the influence of oxidation temperature on the structural, optical, and electrical properties of $\mathrm{Zr}_{0.7} \mathrm{Nb}_{0.3} \mathrm{O}_{2}$ films was reported systematically.

\section{Materials and Methods}

Zirconium niobium oxide $\left(\mathrm{Zr}_{0.7} \mathrm{Nb}_{0.3} \mathrm{O}_{2}\right)$ films were deposited on quartz and p-Type silicon substrates by DC reactive magnetron sputtering technique. The sputtering system employed for the deposition of $\mathrm{Zr}_{0.7} \mathrm{Nb}_{0.3} \mathrm{O}_{2}$ films was the diffusion pump backup by a rotary pump. Pressure in the sputter chamber was measured with Pirani - Penning gauge combination. The sputter deposition conditions fixed for the preparation of $\mathrm{Zr}_{0.7} \mathrm{Nb}_{0.3} \mathrm{O}_{2}$ films were given in the following table.

Table 1. Conditions for preparation of zirconium niobium films by DC magnetron sputtering.

\begin{tabular}{c|c} 
Deposition method & DC magnetron sputtering \\
\hline Sputter target & $\mathrm{Zr}_{0.7} \mathrm{Nb}_{0.3}(99.95 \%$ pure $)$ target \\
\hline Target to substrate distance & $60 \mathrm{~mm}$ \\
\hline Substrates & Quartz and p- Silicon \\
\hline Substrate temperature & $30^{\circ} \mathrm{C}$ \\
\hline Sputter power & $80 \mathrm{Watt}$ \\
\hline Ultimate pressure & $5 \times 10^{-6} \mathrm{Torr}$ \\
\hline Sputter pressure & $6 \times 10^{-3} \mathrm{Torr}$
\end{tabular}

The $\mathrm{Zr}_{0.7} \mathrm{Nb} 0.3$ films were oxidized at different temperatures in the range $500-700{ }^{\circ} \mathrm{C}$ to get $\mathrm{Zr}_{0.7} \mathrm{Nb}_{0.3} \mathrm{O}_{2}$ films. The thickness of the deposited films measured with the Dektak depth profilometer was in the range of $90-110 \mathrm{~nm}$. The $\mathrm{Zr}_{0.7} \mathrm{Nb}_{0.3} \mathrm{O}_{2}$ films elemental composition was analyzed by using an energy dispersive X-ray analyzer (Oxford Instruments Inca Penta FETX3) attached to the scanning electron microscope (Carl Zeiss model EVO MAIS). Chemical bonding configuration was analyzed with Fourier transform infrared spectrophotometer (Thermo-Nicolet model 6700) and core level binding energies by X-ray photoelectron spectroscope (Physical Electronics Model PHI 5700). The structure of the films was studied with an X-ray diffractometer (X'pert Pro PAN Analytical) with $\mathrm{Cu} \mathrm{K} \alpha$ radiation

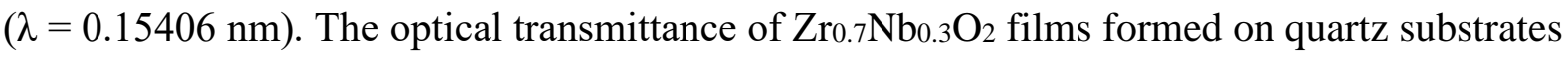
was recorded in the wavelength range 200-1000 nm using JASCO spectrophotometer (model V570) UV-Vis-NIR double beam spectrophotometer to determine the optical band gap and refractive index of the films. Metal-oxide-semiconductor (MOS) capacitors with $\mathrm{Al} / \mathrm{Zr}_{0.7} \mathrm{Nb}_{0.3} \mathrm{O}_{2} / \mathrm{Si}$ stacks were fabricated using a shadow mask of circular capacitors of 300 $\mu \mathrm{m}$ diameter by depositing aluminum metal on the top of the $\mathrm{Zr}_{0.7} \mathrm{Nb}_{0.3} \mathrm{O}_{2}$ films. The capacitance-voltage characteristics of the $\mathrm{Zr}_{0.7} \mathrm{Nb}_{0.3} \mathrm{O}_{2}$ based MOS stacks were measured by using MIOKI (model 3532-50) LCR meter. The current-voltage characteristics were measured using Hewlett Packard (model hp 4140B) pA meter. 


\section{Results and Discussion}

\subsection{Chemical Composition by Energy Dispersive X-ray Analysis.}

The chemical composition of the films formed on silicon substrates was determined by energy-dispersive X-ray (EDAX) analysis. Figure 1 shows the EDAX spectra of as-deposited zirconium niobium films, and the films oxidized at $600{ }^{\circ} \mathrm{C}$ and $700{ }^{\circ} \mathrm{C}$. The metallic zirconium niobium film spectra consist only of the characteristic zirconium and niobium peaks along with silicon peaks. The metallic zirconium niobium films with the chemical content of zirconium 67.8 at. $\%$ and niobium 32.2 at. $\%$ that is $\mathrm{Zr}_{0.68} \mathrm{Nb}_{0.32}$. The films oxidized at temperatures of $600^{\circ} \mathrm{C}$ and $700^{\circ} \mathrm{C}$ have contained the peaks of zirconium, niobium, and oxygen. The chemical composition of the films was determined from the intensity of the peaks and their sensitivity factors and the achieved data is compiled in Table 2. It is clear from the table that the content of oxygen increased with an increase in oxidation temperature.

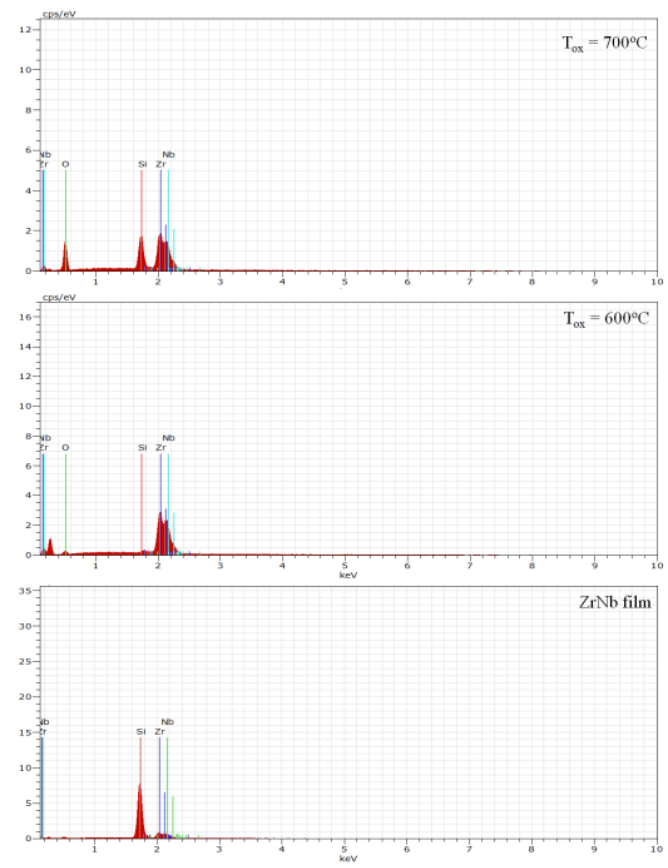

Figure 1. EDAX spectra of as-deposited and thermally oxidized $\mathrm{Zr}_{0.7} \mathrm{Nb}_{0.3} \mathrm{O}_{2}$ films.

Table 2. Chemical composition of $\mathrm{Zr}_{0.7} \mathrm{Nb}_{0.3} \mathrm{O}_{2}$ films determined by EDAX.

\begin{tabular}{c|c|c|c}
\multirow{2}{*}{ Oxidation temperature } & \multicolumn{3}{|c}{ Chemical composition (at.\%) (EDAX) } \\
\cline { 2 - 4 } & Zirconium & Niobium & Oxygen \\
\hline As-deposited & 67.8 & 32.2 & --- \\
\hline $500^{\circ} \mathrm{C}$ & 30.1 & 13.7 & 56.2 \\
\hline $600{ }^{\circ} \mathrm{C}$ & 25.7 & 11.2 & 63.1 \\
\hline $700{ }^{\circ} \mathrm{C}$ & 23.6 & 10.3 & 66.1
\end{tabular}

The films oxidized at $500{ }^{\circ} \mathrm{C}$ consist of significant metallic zirconium ( $\mathrm{Zr}$ ) and niobium $(\mathrm{Nb})$ phases (hence we are not showing the spectra here). The films oxidized at $600{ }^{\circ} \mathrm{C}$ showed the content of zirconium 25.7 at.\%, niobium 11.2 at.\%, and oxygen 63.1 at.\% that is $\mathrm{Zr}_{0.7} \mathrm{Nb}_{0.3} \mathrm{O}_{2}$ along with zirconium and niobium metallic phases. At oxidation temperature of $700{ }^{\circ} \mathrm{C}$ and above showed the composition of zirconium 23.6 at. $\%$, niobium 10.3 at. $\%$ and oxygen 66.1 at. \% indicated the growth of $\mathrm{Zr}_{0.7} \mathrm{Nb}_{0.3} \mathrm{O}_{2}$ with the absence of metallic zirconium and niobium phases. It revealed that the films oxidized at a temperature of $700{ }^{\circ} \mathrm{C}$ were $\mathrm{Zr}_{0.7} \mathrm{Nb}_{0.3} \mathrm{O}_{2}$. 


\subsection{Structural properties.}

Figure 2 shows the $\mathrm{X}$-ray diffraction profiles of the as-deposited and oxidized $\mathrm{Zr}_{0.7} \mathrm{Nb}_{0.3}$ films. No diffraction reflections were seen in the as-deposited, and oxidized $\mathrm{Zr}_{0.7} \mathrm{Nb}_{0.3}$ films up to $600{ }^{\circ} \mathrm{C}$ were amorphous.

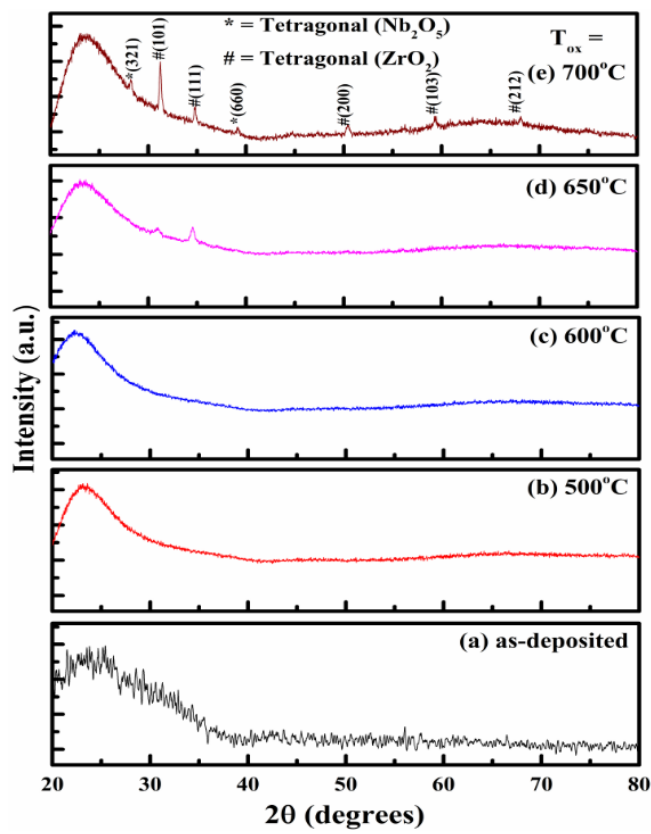

Figure 2. XRD profiles of as-deposited and thermally oxidized $\mathrm{Zr}_{0.7} \mathrm{Nb}_{0.3} \mathrm{O}_{2}$ films.

The films oxidized at $650{ }^{\circ} \mathrm{C}$ showed the diffraction peaks at $2 \theta=31.24^{\circ}$ and $34.78^{\circ}$ related to (101) and (111) reflections of $\mathrm{Nb}_{2} \mathrm{O}_{5}$, and it is in accordance with JCPDS card No. 72.1484. It indicated that the films oxidized at $650{ }^{\circ} \mathrm{C}$ were polycrystalline in nature. The films oxidized at $700{ }^{\circ} \mathrm{C}$ showed the diffraction peaks at $2 \theta=28.24^{\circ}, 39.09^{\circ}, 50.43^{\circ}, 59.34^{\circ}$, and $68.06^{\circ}$ correspond to (321), (660), (200), (103) and (212) reflections of tetragonal $\mathrm{ZrO}_{2}$ in accordance with the JCPDS card No. 42-1164. There was a shift in the $2 \theta$ value of about 0.3 $0.5^{\circ}$ in the diffraction peaks when compared with compounds of $\mathrm{ZrO}_{2}$ and $\mathrm{Nb}_{2} \mathrm{O}_{5}$, which revealed that the niobium substituted the zirconium in $\mathrm{ZrO}_{2}$ and formed with tetragonal structured $\mathrm{Zr}_{0.7} \mathrm{Nb}_{0.3} \mathrm{O}_{2}$. Energy-dispersive $\mathrm{X}$-ray analysis also confirmed that the films oxidized films at $700{ }^{\circ} \mathrm{C}$ were of $\mathrm{Zr}_{0.7} \mathrm{Nb}_{0.3} \mathrm{O}_{2}$. Santos et al. [20] reported that the niobiumdoped $\mathrm{ZrO}_{2}$ films $(\mathrm{Nb}=20-50$ wt. \%) deposited by the electrochemical method were mixed phases of hexagonal zirconium, monoclinic and tetragonal phase $\mathrm{ZrO}_{2}$ with different crystallographic phases of $\mathrm{Nb}_{2} \mathrm{O}_{5}$. The crystallite size (D) of the films was calculated using Debye-Scherrer's relation,

$$
\mathrm{D}=0.9 \lambda / \beta \cos \theta
$$

where $\lambda$ is the wavelength of copper X-ray radiation, $\beta$ the full width at half maximum intensity of diffraction peak, and $\theta$ the diffraction angle. The crystallite size of the films increased from $8 \mathrm{~nm}$ to $22 \mathrm{~nm}$ with an increase of oxidation temperature from $650{ }^{\circ} \mathrm{C}$ to $700{ }^{\circ} \mathrm{C}$, respectively. The increase in the crystallite size with oxidation temperature was due to an improvement in the crystallinity of films. Dislocation density $(\delta)$ and strain $(\varepsilon)$ developed in the films were calculated from the $\mathrm{X}$-ray diffraction peaks employing the relation,

$$
\delta=1 / \mathrm{D} 2
$$

and

$$
\varepsilon=\beta \cos \theta / 4
$$


Dislocation density and strain developed in the films were calculated from the X-ray diffraction peaks decreased from $27.7 \times 10^{16} \mathrm{lines} / \mathrm{m}^{2}$ to $2.0 \times 10^{16} \mathrm{lines} / \mathrm{m}^{2}$, and stain decreased from $21.2 \times 10^{-3}$ to $5.9 \times 10^{-3}$ with the increase of oxidation temperature from $650{ }^{\circ} \mathrm{C}$ to $700{ }^{\circ} \mathrm{C}$, respectively. The decrease in the dislocation density and strain with an increase of crystallite size was observed along with the increase of oxidation temperature.

\subsection{Surface morphology.}

The surface morphology of the films was studied using a scanning electron microscope. Figure 3 shows the scanning electron micrographs of as-deposited $\mathrm{Zr}_{0.7} \mathrm{Nb}_{0.3}$ films and the films oxidized at different temperatures. The grain size of the $\mathrm{Zr}_{0.7} \mathrm{Nb}_{0.3} \mathrm{O}_{2}$ films increased from 97 $\mathrm{nm}$ to $118 \mathrm{~nm}$ with an increase of oxidation temperature from $600{ }^{\circ} \mathrm{C}$ to $700{ }^{\circ} \mathrm{C}$. With the increase of oxidation temperature, there was a subsequent increase in the grain size of $\mathrm{Zr}_{0.7} \mathrm{Nb}_{0.3} \mathrm{O}_{2}$ films.
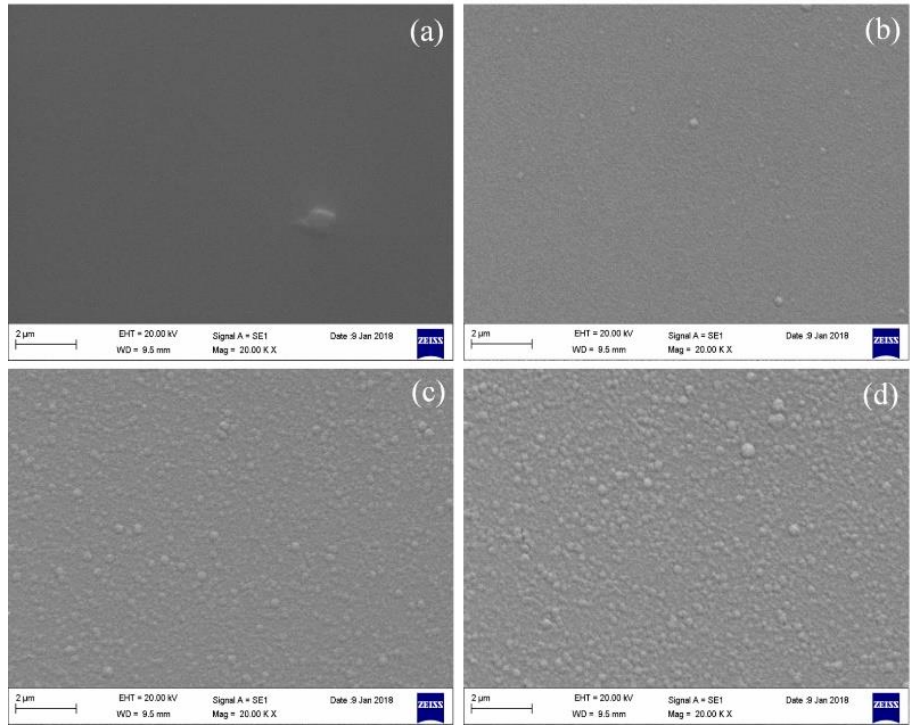

Figure 3. SEM images $\mathrm{Zr}_{0.7} \mathrm{Nb}_{0.3} \mathrm{O}_{2}$ films of (a) as-deposited; thermally oxidized at (b) $500^{\circ} \mathrm{C} ;(\mathbf{c}) 600^{\circ} \mathrm{C}$; (d) $700^{\circ} \mathrm{C}$.

\subsection{X-ray photoelectron spectroscopic studies.}

Figure 4 shows survey (Figure 4a) and narrow scan XPS spectra $\mathrm{Zr}_{0.7} \mathrm{Nb}_{0.3}$ films oxidized at $700{ }^{\circ} \mathrm{C}$. Narrow scan spectrum of zirconium $\mathrm{Zr} 3 \mathrm{~d}$ (Figure 4b), niobium $\mathrm{Nb} 3 \mathrm{~d}$ (Figure $4 \mathrm{c}$ ), and oxygen $\mathrm{O}$ 1s (Figure $4 \mathrm{~d}$ )extracted from $\mathrm{Zr}_{0.7} \mathrm{Nb}_{0.3} \mathrm{O}_{2}$ films. All these spectra revealed the existence of $\mathrm{Nb}$ along with the $\mathrm{Zr}$ and $\mathrm{O}_{2}$. The core-level binding energies located at about $180.35 \mathrm{eV}$ and $182.73 \mathrm{eV}$ related to the zirconium $\mathrm{Zr} \mathrm{3d_{3/2 }}$ and $\mathrm{Zr} 3 \mathrm{~d}_{5 / 2}$ due to spinorbit splitting with separation in the energy of $2.38 \mathrm{eV}$ revealed the $\mathrm{Zr}^{4+}$ state $\mathrm{ZrO}_{2}[19,20]$. The binding energies are seen at $205.29 \mathrm{eV}$, and $208.11 \mathrm{eV}$ correspond to niobium $\mathrm{Nb} 3 \mathrm{~d}_{3 / 2}$ and $\mathrm{Nb} 3 \mathrm{~d}_{5 / 2}$, and the energy separation of $2.82 \mathrm{eV}$ revealed the $\mathrm{Nb}^{5+}$ sate that is niobium oxide $[21,22]$. On the other hand, Figure $4 \mathrm{~d}$ showed the $\mathrm{O} 1$ s core-level binding energy at $29.1 \mathrm{eV}$, which is the possible evidence for the stoichiometric zirconium niobium oxides films. It was noted that the core level binding energies were shifted about $0.3 \mathrm{eV}$ in $\mathrm{Zr} 3 \mathrm{~d}$ and $\mathrm{Nb} 3 \mathrm{~d}$, which confirms that the grown films were indicated $\mathrm{Zr}_{0.7} \mathrm{Nb}_{0.3} \mathrm{O}_{2}$ films. 

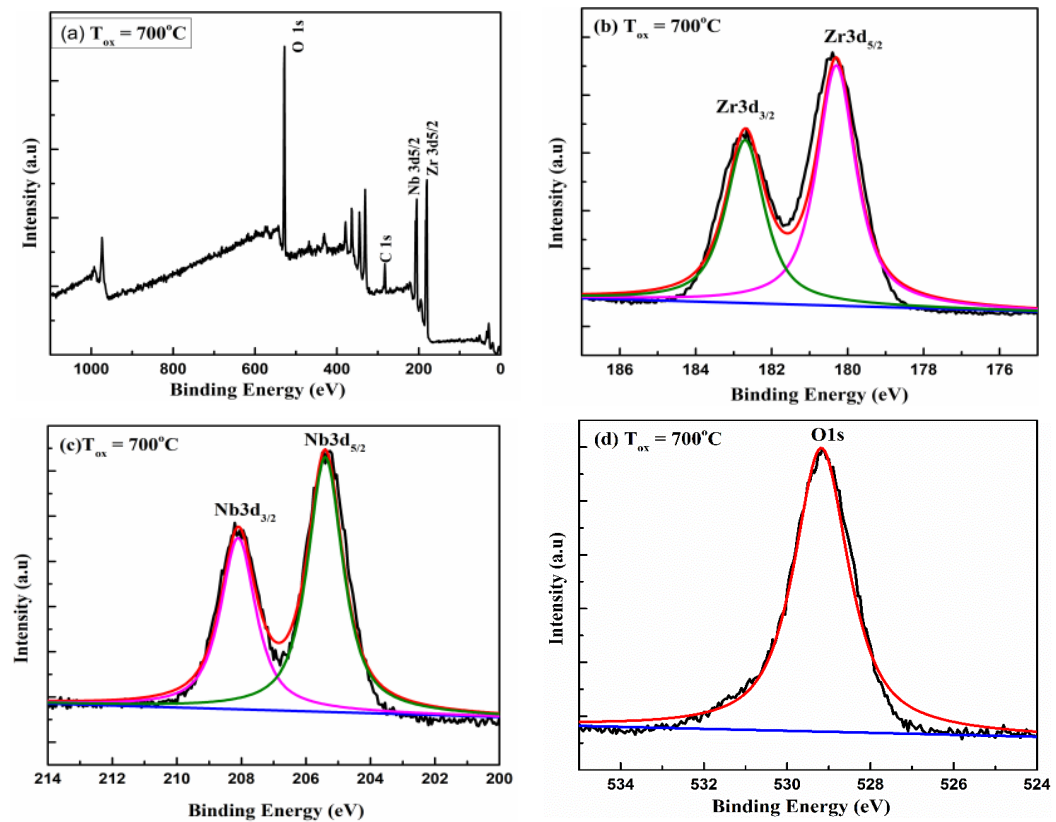

Figure 4. XPS spectrum of $\mathrm{Zr}_{0.7} \mathrm{Nb}_{0.3} \mathrm{O}_{2}$ films oxidized at $700^{\circ} \mathrm{C}$ : (a) survey scan; narrow scan spectra of (b) $\mathrm{Zr}$ $3 \mathrm{~d} ;(\mathbf{c}) \mathrm{Nb} 3 \mathrm{~d} ;$ (d) $\mathrm{O} 1 \mathrm{~s}$.

\subsection{Fourier transform infrared studies.}

The chemical binding configuration of the films formed on p- silicon was examined with Fourier transform infrared spectroscope. Fourier transforms infrared transmittance spectra of the films oxidized at different temperatures are shown in Figure 5. Metallic $\mathrm{Zr}_{0.7} \mathrm{Nb}_{0.3}$ films did not show absorption bands in the spectrum. The films oxidized at $500{ }^{\circ} \mathrm{C}$ exhibited the absorption bands at $505 \mathrm{~cm}^{-1}, 600 \mathrm{~cm}^{-1}, 620 \mathrm{~cm}^{-1}, 740 \mathrm{~cm}^{-1}$ and $1110 \mathrm{~cm}^{-1}$. The band located at $515 \mathrm{~cm}^{-1}$ and $600 \mathrm{~cm}^{-1}$ were attributed to the antisymmetric stretching mode of $\mathrm{Zr}-\mathrm{O}$ and 740 $\mathrm{cm}^{-1}$ due to the symmetric stretching mode of $\mathrm{Zr}-\mathrm{O}$ in $\mathrm{ZrO}_{2}$ films [23]. The absorption bands were seen at $620 \mathrm{~cm}^{-1}$, and $1110 \mathrm{~cm}^{-1}$ were the stretching vibration mode of $\mathrm{Nb}-\mathrm{O}$ of $\mathrm{Nb}_{2} \mathrm{O}_{5}[24]$. Further increase of oxidation temperature intensity of absorption band increased due to improved crystallinity of the $\mathrm{Zr}_{0.7} \mathrm{Nb}_{0.3} \mathrm{O}_{2}$ films. In the case of the films oxidized at 700 ${ }^{\circ} \mathrm{C}$, the absorption band $505 \mathrm{~cm}^{-1}$ was shifted to $515 \mathrm{~cm}^{-1}$. It is also confirmed that the oxidized films at around $700{ }^{\circ} \mathrm{C}$ were of $\mathrm{Zr}_{0.7} \mathrm{Nb}_{0.3} \mathrm{O}_{2}$ films.

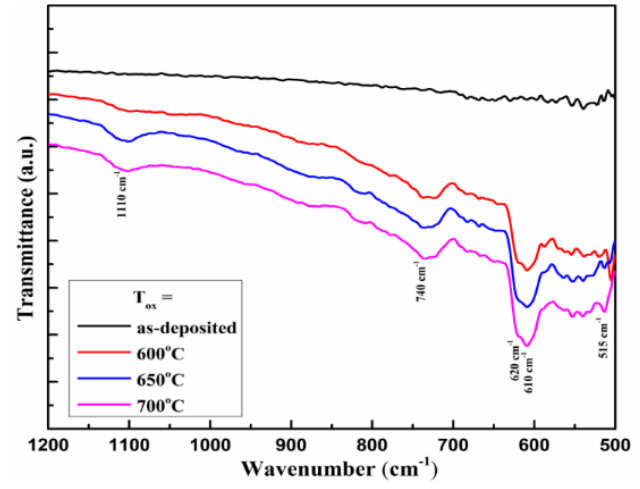

Figure 5. FTIR transmittance spectra of as-deposited and thermallyoxidized $\mathrm{Zr}_{0.7} \mathrm{Nb}_{0.3} \mathrm{O}_{2}$ films.

\subsection{Optical properties.}

Figure 6shows the optical transmittance spectra of the films oxidized at different temperatures. The optical transmittance of the films increased from 75 to $\sim 90 \%$ in the visible region with the increase of oxidation temperature from $400^{\circ} \mathrm{C}$ to $750{ }^{\circ} \mathrm{C}$. 


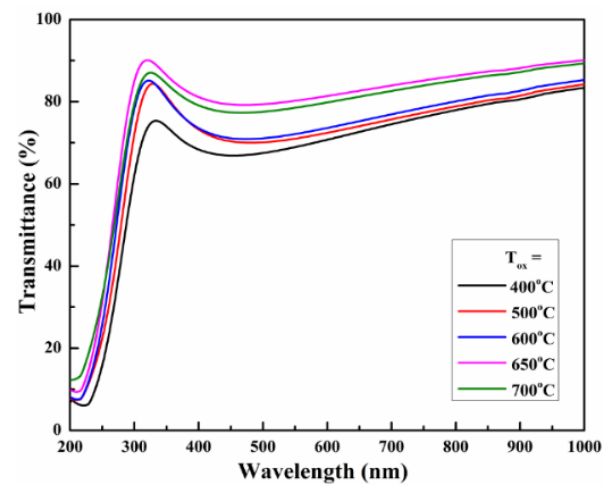

Figure 6. Optical transmittance spectra of as-deposited and thermally oxidized $\mathrm{Zr}_{0.7} \mathrm{Nb}_{0.3} \mathrm{O}_{2}$ films.

The low transmittance at oxidation temperatures at $400{ }^{\circ} \mathrm{C}$ was due to the incomplete transformation of $\mathrm{Zr} 0.7 \mathrm{Nb}_{0.3}$ films into $\mathrm{Zr} 0.7 \mathrm{Nb}_{0.3} \mathrm{O}_{2}$ films and also the presence of some defects in the targeted oxide films $[25,26]$. The fundamental absorption edge of the films shifted towards the lower wavelength side due to the filling of oxygen ion vacancies in the $\mathrm{Zr}_{0.7} \mathrm{Nb}_{0.3} \mathrm{O}_{2}$ films. The optical absorption coefficient $(\alpha)$ was determined from the optical transmittance $(\mathrm{T})$ and thickness $(\mathrm{t})$ of the films using the relation

$$
\alpha=-(1 / \mathrm{t}) \ln (\mathrm{T})
$$

In order to determine the optical band gap (Eg), the optical absorption data of the films was fitted to the relation [27],

$$
(\alpha h v)^{2}=\mathrm{A}\left(\mathrm{h} v-\mathrm{Eg}_{\mathrm{g}}\right)
$$

where $\mathrm{h} v$ is the photon energy and $\mathrm{E}_{\mathrm{g}}$ the optical bandgap. The optical bandgap of the films was determined from Tauc's plots. Figure 7 shows the plots of $(\alpha h v)^{2}$ versus photon energy of $\mathrm{Zr}_{0.7} \mathrm{Nb}_{0.3} \mathrm{O}_{2}$ films oxidized at different temperatures.

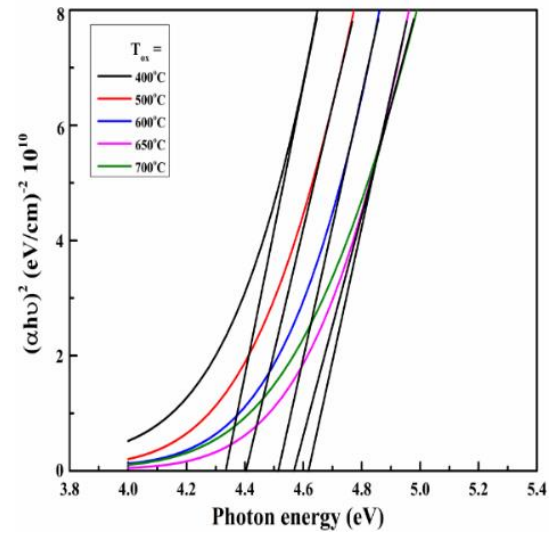

Figure 7. Plots of $(\alpha h v)^{2}$ versus photon energy of thermally oxidized $\mathrm{Zr}_{0.7} \mathrm{Nb}_{0.3} \mathrm{O}_{2}$ films.

The optical bandgap of the films oxidized at $400^{\circ} \mathrm{C}$ was $4.32 \mathrm{eV}$, and it increased from $4.40 \mathrm{eV}$ to $4.61 \mathrm{eV}$ with an increase of oxidation temperature from $500{ }^{\circ} \mathrm{C}$ to $700{ }^{\circ} \mathrm{C}$. The low optical bandgap in the films oxidized at low temperatures was due to oxygen deficiency, that is, the excess of metallic zirconium and niobium along $\mathrm{Zr}_{0.7} \mathrm{Nb}_{0.3} \mathrm{O}_{2}$. The $\mathrm{Zr}_{0.7} \mathrm{Nb}_{0.3} \mathrm{O}_{2}$ films oxidized at $700{ }^{\circ} \mathrm{C}$ showed a large bandgap of $4.61 \mathrm{eV}$. As the oxidation temperature increases, the thermal energy given accelerates to fill the oxygen ion vacancies, thereby increasing the optical bandgap. Larijani et al.[28] noticed that DC magnetron sputtered zirconium films transformed into $\mathrm{ZrO}_{2}$ with an optical band gap of $4.08 \mathrm{eV}$ at the oxidation of $450^{\circ} \mathrm{Cand} 5.15$ $\mathrm{eV}$ in electron beam deposited films [29]. In the case of $\mathrm{Nb}_{2} \mathrm{O}_{5}$ films deposited by $\mathrm{RF}$ magnetron sputtering, the optical band gap decreased from $3.62 \mathrm{eV}$ to $3.07 \mathrm{eV}$ with an increase of annealing in air at temperatures from $30^{\circ} \mathrm{C}$ to $900^{\circ} \mathrm{C}$ [30] and increased from $3.29 \mathrm{eV}$ to 3.46 
$\mathrm{eV}$ with an increase of sputter power [31]. The optical bandgap of $\mathrm{TiO}_{2}$ films also increased with annealing temperature [32].

\subsection{Electrical and dielectric properties.}

Figure 8 shows the capacitance-voltage $(\mathrm{C}-\mathrm{V})$ curves of the $\mathrm{Al} / \mathrm{Zr}_{0.7} \mathrm{Nb}_{0.3} \mathrm{O}_{2} / \mathrm{Si}$ stacks of thermally oxidized $\mathrm{Zr}_{0.7} \mathrm{Nb}_{0.3}$ thin film with the thickness of $\sim 99 \mathrm{~nm}$. The accumulation capacitance value of the $\mathrm{Zr}_{0.7} \mathrm{Nb}_{0.3} \mathrm{O}_{2} / \mathrm{Si}$ stacks was decreased from $\sim 0.69$ to $0.61 \mu \mathrm{F} / \mathrm{cm}^{2}$ by increasing oxidation temperature from 500 to $700{ }^{\circ} \mathrm{C}$, respectively. The possible reason for this reduction in accumulation capacitance could be due to the strengthening of the interfacial $\mathrm{SiO}_{2}$ layer at $\mathrm{Zr}_{0.7} \mathrm{Nb}_{0.3} \mathrm{O}_{2} / \mathrm{Si}$ stacks $[33,34]$. Pure $\mathrm{ZrO}_{2} / \mathrm{Si}$ stacks struggled with low dielectric properties and eventually unstable interface at higher temperatures [35], whereas here we observed the stable $\mathrm{C}-\mathrm{V}$ curve of $\mathrm{Zr}_{0.7} \mathrm{Nb}_{0.3} \mathrm{O}_{2} / \mathrm{Si}$ stacks after the thermal treatment at $700{ }^{\circ} \mathrm{C}$.

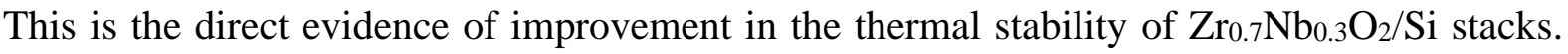
Besides, there was a significant positive shift in the $\mathrm{C}-\mathrm{V}$ curve of the stacks oxidized at the temperature of $700{ }^{\circ} \mathrm{C}$, which might be due to the filling of oxygen vacancies in the oxide layer and the reduction in fixed charges at the oxide/semiconductor interface [36].

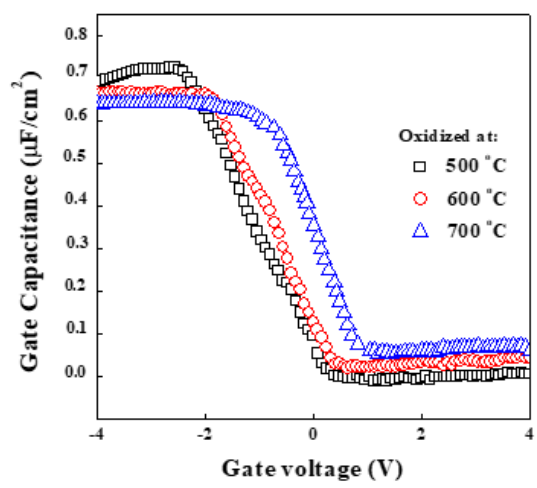

Figure 8. Capacitance - voltage characteristics of $\mathrm{Al} / \mathrm{Zr}_{0.7} \mathrm{Nb}_{0.3} \mathrm{O}_{2} / \mathrm{Si}$ capacitors formed at different oxidation temperatures.

The dielectric constant $\left(\varepsilon_{\mathrm{r}}\right)$ of the films was calculated from the C-V measurements using the formula

$$
\varepsilon_{\mathrm{r}}=\mathrm{Ct} / \varepsilon_{\mathrm{o}} \mathrm{A}
$$

where $\mathrm{C}$ is the capacitance, ' $\mathrm{t}$ ' the thickness of the dielectric, $\mathrm{A}$ the area of the electrode, and $\varepsilon_{o}$ the permittivity of the free space. The dielectric constant of the $\mathrm{Al} / \mathrm{Zr}_{0.7} \mathrm{Nb}_{0.3} \mathrm{O}_{2} / \mathrm{Si}$ stacks annealed at $500{ }^{\circ} \mathrm{C}$ was 9 and increased to 11 and 14 by increasing the annealing temperature $600{ }^{\circ} \mathrm{C}$ and $700{ }^{\circ} \mathrm{C}$, respectively. Figure 9shows the current-voltage characteristics of

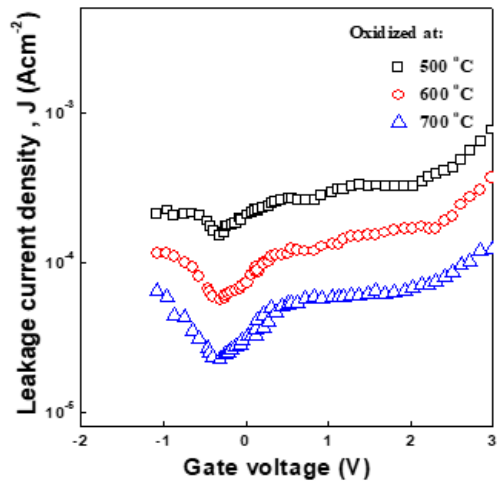

Figure 9. Current-voltage characteristics of $\mathrm{Al} / \mathrm{Zr}_{0.7} \mathrm{Nb}_{0.3} \mathrm{O}_{2} /$ Sicapacitors formed at different oxidation temperatures. 
$\mathrm{Al} / \mathrm{Zr}_{0.7} \mathrm{Nb}_{0.3} \mathrm{O}_{2} / \mathrm{p}-\mathrm{Si}$ stacks annealed at 500,600 , and $700^{\circ} \mathrm{C}$. The leakage current density was decreased from $2 \times 10^{-4} \mathrm{~A} / \mathrm{cm}^{2}$ to $\sim 3 \times 10^{-5} \mathrm{~A} / \mathrm{cm}^{2}$ by increasing the thermal oxidation temperature from $500{ }^{\circ} \mathrm{C}$ to $700{ }^{\circ} \mathrm{C}$, respectively. The reduction in the leakage current value might be due to the strengthening of the stable $\mathrm{SiO}_{2}$ layer at high-k/Si stacks [36]. The leakage current densities versus voltage curves combine linear and non-linear regions due to the current assimilation mechanism, such as Schottky Poole- Frenkel. The shifting of lower leakage current density value at the applied gate voltage of $0 \mathrm{~V}$ is under investigation.

\section{Conclusions}

Thin films of zirconium niobium oxide $\left(\mathrm{Zr}_{0.7} \mathrm{Nb}_{0.3} \mathrm{O}_{2}\right)$ were prepared by thermal oxidation of metallic DC magnetron sputtered $\mathrm{Zr}_{0.7} \mathrm{Nb}_{0.3}$ films onto quartz and p- silicon substrates held at room temperatures. The oxidation temperature controls the growth of $\mathrm{Zr}_{0.7} \mathrm{Nb}_{0.3} \mathrm{O}_{2}$ films. EDAX analysis studies showed that the films oxidized at temperatures less than $600{ }^{\circ} \mathrm{C}$ were of mixed-phase of metallic zirconium and niobium along with $\mathrm{Zr}_{0.7} \mathrm{Nb}_{0.3}$ whereas those oxidized at $700{ }^{\circ} \mathrm{C}$ were tetragonal structures $\mathrm{Zr}_{0.7} \mathrm{Nb}_{0.3} \mathrm{O}_{2}$. Fourier transform infrared spectroscopy and X-ray photoelectron spectroscopic studies confirmed the presence of characteristic vibration modes of $\mathrm{Zr}-\mathrm{O}$ and $\mathrm{Nb}-\mathrm{O}$ and core level binding energies related to $\mathrm{Zr}_{0.7} \mathrm{Nb}_{0.3} \mathrm{O}_{2}$ upon high-temperature oxidation. The dielectric constant value and bottom interfacial properties of $\mathrm{Al} / \mathrm{Zr}_{0.7} \mathrm{Nb}_{0.3} \mathrm{O}_{2} / \mathrm{Si}$, MOS stacks were improved by increasing oxidation temperature from $500{ }^{\circ} \mathrm{C}$ to $700{ }^{\circ} \mathrm{C}$, because of filling the oxygen vacancies in and around the oxide layer. The leakage currents were also reduced to the order of $10^{-5}$ for the stacks oxidized at $700{ }^{\circ} \mathrm{C}$. The thermal stability of the investigated oxide layer with Si substrate was improved by the addition of $\mathrm{Nb}$ into $\mathrm{Zr}$. Further investigations may give more attractive results of this high-k alloy.

\section{Funding}

This research received no external funding.

\section{Acknowledgments}

One of the authors, Dr. S. Uthanna, is thankful to the University Grants Commission, New Delhi, India, for the UGC-BSR Faculty Fellowship award.

\section{Conflicts of Interest}

The authors declare no conflict of interest.

\section{References}

1. Huan, L.; Han, G.; Liu, Y.; Hao, Y. High Mobility Ge pMOSFETs with $\mathrm{ZrO}_{2}$ Dielectric: Impacts of PostAnnealing. Nanoscale Res Lett.2019, 14,https://doi.org/10.1186/s11671-019-3037-4.

2. Kondaiah, P.; Jagadeesh Chandra, S.V.; Fortunato, E.; Choi C.J.; Mohan Rao, GRama Koti Reddy, D.V.; Uthanna, S. Substrate temperature influenced $\mathrm{ZrO}_{2}$ films for MOS devices. Surf.Inter. Anal. 2020, 52,541546,https://doi.org/10.1002/sia.6775.

3. Horti, N.C.; Kamatagi, M.D.; Nataraj, S.K.; Wari, M.N.; Inamdar, S.R. Structural and optical properties of zirconium oxide $\left(\mathrm{ZrO}_{2}\right)$ nanoparticles: effect of calcination temperature. Nano Exp.2020,1, 010022, https://doi.org/10.1088/2632-959X/ab8684. 
4. Dimitrov, O.; Stambolova, I.; Vassilev, S.; Lazarova, K.; Babeva, T.; Mladenova, R. Surface Features of $\mathrm{ZrO}_{2}$ Sol-Gel Coatings Obtained by Polymer Modified Solution.Mater.Proc.2020, 2, 1-8, https://doi.org/10.3390/CIWC2020-06810.

5. Thakar, K.; Saurabh, L. Optoelectronic and photonic devices based on transition metal dichalcogenides. Mater. Res. Express 2020, 7, 014002,https://doi.org/10.1088/2053-1591/ab5c9c.

6. Li, N.; Suzuki, M.; Abe, Y.; Kawamura, M.; Sasaki, K.; Itoh, H.; Suzuki, T. Effects of substrate temperature on the ion conductivity of hydrated $\mathrm{ZrO}_{2}$ thin films prepared by reactive sputtering in $\mathrm{H}_{2} \mathrm{O}$ atmosphere. Solar Energy Mater. Solar Cells2012, 99,160-165,https://doi.org/10.1016/j.solmat.2011.03.037.

7. Roy, M.; Kubacki, J.; Psiuk, B.; Wilczkiewicz, A.M.; Malarz, K.; Corti, A.; Pompella, A.; Szade, J. Photofunctionalization effect and biological ageing of PEEK, $\mathrm{TiO}_{2}$ and $\mathrm{ZrO}_{2}$ abutments material. Mater. Sci. Engg. C 2021, 121, 111823,https://doi.org/10.1016/j.msec.2020.111823.

8. Berlin, I.J.; Joy, K. Optical enhancement of Au doped $\mathrm{ZrO}_{2}$ thin films by sol-gel dip coating method. Physica B 2015,457, 182,https://doi.org/10.1016/j.physb.2014.10.013.

9. Alfeche, D.M.; Cervera, R.B. Highly conducting Sc and Y co-doped ZrO2 thin film solid electrolyte on aporous Ni/YSZ electrode prepared via simple drop-coating method. Ceram. Int. 2020, 46, 10561-10567, https://doi.org/10.1016/j.ceramint.2020.01.058.

10. Arjun, A.; Dharr, A.; Raguram, T.; Rajni, K. S. Study of Copper Doped Zirconium Dioxide Nanoparticles Synthesized via Sol-Gel Technique for Photocatalytic Applications. J. Inorgan. Organ. Polym. Mater. 2020, 30, 4989-4998, https://doi.org/10.1007/s10904-020-01616-4.

11. Kim, K.D.; Lee, Y.H.; Gwon, T.; Kim, Y.T.; Kim, H.J.; Moon, T.; Hyun, S.D.; Park, H.W.; Park, M.H.; Hwang, C.S. Scale-up and optimization of $\mathrm{HfO}_{2}-\mathrm{ZrO}_{2}$ solid solution thin films for the electrostatic supercapacitors. Nano Energy 2017, 39, 390-399, https://doi.org/10.1016/j.nanoen.2017.07.017.

12. El-Lateef, H.M.A.; Khalif, M.M. Corrosion resistance of $\mathrm{ZrO}_{2}-\mathrm{TiO}_{2}$ nanocomposite multilayer thin films coated on carbon steel in hydrochloric acid solution. Mater. Charact. 2015, 108, 29-41, https://doi.org/10.1016/j.matchar.2015.08.010.

13. Simonenko, E.P.; Mokrushin, A.S.; Simonenko, N.P.; Voronov, V.A.; Kim, V.P.; Thachev, S.V.; Gubin, S.P.; Sevaslyanov, V.G.; Kuznetsov, N. Ink-jet printing of a $\mathrm{TiO}_{2}-10 \% \mathrm{ZrO}_{2}$ thin film for oxygen detection using a solution of metal alkoxoacetylacetonates. Thin Solid Films 2019, 670, 46-53, https://doi.org/10.1016/j.tsf.2018.12.004.

14. Wu, M.; Yu, S.; Wang, X.; Li, L. Influence of substrate temperature on the energy storage properties of bismuth magnesian niobium thin films prepared by magnetron sputtering. Ceram. Internation. 2021, 47, 8265-8270, https://doi.org/10.1016/j.ceramint.2020.11.186.

15. Senocak, T.C.; Ezirmik, K.V.; Aysin, F.; Ozek, N.S.; Cengiz, S. Niobium-oxynitride coatings for biomedical applications: Its antibacterial effects and in-vitro cytotoxicity. Mater. Sci. Engg. C 2021, 120, 111662, https://doi.org/10.1016/j.msec.2020.111662.

16. Khamseh, S.; Alibakhshi, E.; Ramezanzadeh, B.; GanjaeeSari, M.; Nezhad, A.K. Developing a Graphite like Carbon:Niobium thin film on GTD-450 stainless steel substrate. Appl. Surf. Sci. 2020, 511, 145613, https://doi.org/10.1016/j.apsusc.2020.145613.

17. Mokhtar, A.M.; Salem, K.E.; Allam, N.K. Multiple synergistic effects of Zr-alloying on the phase stability and photostability of black niobium oxide nanotubes as efficient photoelectrodes for solar hydrogen production. Appl. Catal. B: Env. 2021, 287, 119961, https://doi.org/10.1016/j.apcatb.2021.119961.

18. Mishchenko, O.; Ovchynnykov, O.; Kapustian, O.; Pogorielov, M. New Zr-Ti-Nb Alloy for MedicalApplication: Development, Chemical and Mechanical Properties, and Biocompatibility. Materials 2020, 13, 1306, https://doi.org/10.3390/ma13061306.

19. Ji, P.F.; Li, B.; Chen, B.H.; Wang, F.; MaX, W.; Zhang, Y.; Ma, M.Z.; Liu, R.P. Effect of Nb addition onthe stability and biological corrosion resistance of $\mathrm{Ti}-\mathrm{Zr}$ alloy passivation films. Corrosion Sci. 2020, 170,108696, https://doi.org/10.1016/j.corsci.2020.108696.

20. Santos, J.S.; Strixino, F.T.; Pereira, E.C. The influence of experimental conditions on the morphology and phase composition of $\mathrm{Nb}$-doped $\mathrm{ZrO}_{2}$ films prepared by spark anodization. Corrosion Sci. 2013, 73, 99-105, https://doi.org/10.1016/j.corsci.2013.03.029.

21. Hong, J.H.; Choi, W.J.; Myoung, J.M. Microelectron. Properties of $\mathrm{ZrO}_{2}$ dielectric layers grown by metalorganic molecular beam epitaxy. Microelectron. Eng. 2003, 70, 35-40, https://doi.org/10.1016/S01679317(03)00388-5. 
22. Maiti, C.K.; Dalapathi, G.K.; Chatterjee, S.; Samanta, S.K.; Varma, S.; Patil, S. Electrical properties of high permittivity $\mathrm{ZrO} 2$ gate dielectrics on strained-Si. Solid State Electron. 2004, 48, 2235-2241, https://doi.org/10.1016/j.sse.2004.04.012.

23. Lee, S.H.; Kwon, J.D.; Park, J.S. Compositional and electrical modulation of niobium oxide thin films deposited by plasma-enhanced atomic layer deposition. Ceram. Int. 2017, 43, 6580-6584, https://doi.org/10.1016/j.ceramint.2017.02.089.

24. Mazur, M.; Synmanska, M.; Kaemarck, D.; Kalisz, M.; Wojcieszak, D.; Domaradzki, J.; Placido, F. Determination of optical and mechanical properties of $\mathrm{Nb}_{2} \mathrm{O}_{5}$ thin films for solar cells application. Appl. Surf. Sci. 2014, 301, 63-69, https://doi.org/10.1016/j.apsusc.2014.01.144.

25. Nakajima, K.; Baba, Y.; Noma R.; Kitano, M.; Kondo, J.N.; Hayashi, S.; Hara, M. $\mathrm{Nb}_{2} \mathrm{O}_{5} \cdot \mathrm{nH}_{2} \mathrm{O}$ as a Heterogeneous Catalyst with Water-Tolerant Lewis Acid Sites, J. Am. Chem. Soc. 2011, 133, 4224-4227, https://doi.org/10.1021/ja110482r.

26. Venkataiah, S.; Jagadeesh Chandra, S.V.; Chalapathi, U.; Ramana, Ch.V.V.; Uthanna, S. Oxygen partial pressure influenced stoichiometry, structural, electrical, and optical properties of DC reactive oxide films. Sur. Inter. Anal. 2021, 53, 206-214, https://doi.org/10.1002/sia.6902.

27. Tauc, J. Optical Properties of Amorphous Semiconductors. In Amorphous and Crystalline Semiconductors, Plenum Press, NY, 1974, https://doi.org/10.1007/978-1-4615-8705-7_4.

28. Larijani, M.M.; Hasani, E.; Safa, S. Annealing temperature effect on the optical properties of thermally oxidized nano-crystalline $\mathrm{ZrO}_{2}$ thin films grown on glass substrates. Appl. Surf. Sci. 2014, 290, 490-494, https://doi.org/10.1016/j.apsusc.2013.11.131.

29. Ling, X.; Liu, X.; Wang, G.; Fan, Z. Influence of oxygen partial pressure on laser-induced damage resistance of $\mathrm{ZrO}_{2}$ films in vacuum. Vacuum 2015, 119, 145-150, https://doi.org/10.1016/j.vacuum.2015.05.012.

30. Atta, A.A.; EL-Nahass, M.M.; Hassanian, A.M.; Elsabawy, K.M.; EL-Raheem, M.M.A.; Alhuthali, A.; S.E.; Algamdi, M.S. Effect of thermal annealing on structural, optical and electrical properties of transparent $\mathrm{Nb}_{2} \mathrm{O}_{5}$ thin films. Mater. Today Commun. 2017, 13, 112-118, https://doi.org/10.1016/j.mtcomm.2017.09.004.

31. Korkmaz, S.; Pat, S.; Ekem, N.; Balbag, M.Z.; Temel, S. Thermal treatment effect on the optical properties of $\mathrm{ZrO}_{2}$ thin films deposited by thermionic vacuum arc. Vacuum 2012, 86, 1930-1933, https://doi.org/10.1016/j.vacuum.2012.05.002.

32. Chandra Sekhar, M.; Kondaiah, P.; Mohan Rao, G.; Jagadeesh Chandra, S.V.; Uthanna, S. Post-deposition annealing influenced structural and electrical properties of $\mathrm{Al} / \mathrm{TiO}_{2} / \mathrm{Si}$ gate capacitors. Superlattices and Microstructures 2013, 62, 68-80, http://dx.doi.org/10.1016/j.spmi.2013.07.001.

33. Kim, J.; Haga, K.; Tokumitsu, E. Investigation of Nb-Zr-O Thin Film using Sol-gel Coating. J. Semiconduct. Technol. Sci. 2017, 17, 245-251, https://doi.org/10.5573/JSTS.2017.17.2.245.

34. Jagadeesh Chandra, S.V.; Mi-Ra, J.; Shim, K.H.; Hong, H.B.; Lee, S.H.; Ahn, K.S.; Choi, C.J. Effective Metal Work Function of Pt Gate Electrode in Ge Metal Oxide Semiconductor Device. J Electrochem. Soc. 2010, 157, H546-H550, https://doi.org/10.1149/1.3332849.

35. Jagadeesh Chandra, S.V.; Fortunato, E.; Martins, R.; Choi, C.J. Modulations in effective work function of platinum gate electrode in metal-oxide-semiconductor devices. Thin Solid Films 2012, 520, 4556-4558, https://doi.org/10.1016/j.tsf.2011.10.137.

36. Hayath Rajvee, Md.; Jagadeesh Chandra, S.V.; Rajesh Kumar, P.; Ramana, CH.V.V.; Neelama, K.; Dubey,R. S. Synthesis and Analysis of Zirconium Titanate Thin Films by using Sol-Gel Method. Biointer. Res. Appl. Chem. 2021, 11, 12761, https://doi.org/10.33263/BRIAC115.1276112768. 